Public-data File $84-48$

METALLOGENY OF THE TOLOVANA MINING DISTRICT, EAST-CENTRAL ALASKA

By

M.S. Robinson

Alaska Division of

Geological and Geophyslcal Surveys

1984

THIS REPORT HAS NOT BEEN REVIEWED FOR TECHNICAL CONTENT (EXCEPT AS NOTED IN

TEXT) OR FOR CONFORMITY TO THE

EDITORIAL STANDARDS OF DGGS.

794 University Avenue, Basement

Falrbanks, Alaska 99701 
reicizogeny of the Tolovane gining cistrict, east-centrei fleske by

\author{
M.S. RObinson
}

The Iolovanis mining. district is centered near the tow of Iivengood, epproxiogtels 70 miles northwest of Feirbanks, in east-central Alaska. Figure 1 is a simplified geologic mapi of the erea surrounding livengood.

Bedrock exposed in the region is dominated by a complexiy deformed sequence that ranges in ege from Cembrian to Cretaceous. This sequence, although cectonically dismembered, hes close affinities to rocks of the Selwy basin and Cassiar Platforw in eestern and centel Yukon Terricor, Canada (Chapman and others, 1980, Robinson and orhers, 1983, ano Tempelman - Riuit, 1984).

The oldest rocks in the Livengood eree (the Grit unit) comprise en interlayered sequeace of tároon and greer. slete, black slate, dark gray limestone, vitreous quertzite and bimodal quartz sadstcne (grit). The green slate of this vait contains the trace fossil Oldhamia and hes beed assigned an Early Cembrien age (Churkin add Brebb, 1965). Sinilar rocks in the Yukct Ierritory are included in The Grit Inte of Gebrielse and others (1973) ano ere believed ro floor the Selugh Basin enć Cassier Platform (Tempelmen - Kluit, 1984). Southeest of Livengood, 'rocks of tine Grit unit are apperently thrust over a Cabro-Ordovician sequence of sheerec volcanics ouartzizes ano slate, thet ere considered to de equivelent to the Eossil Creek Pclcanics in the hrite Mounteins anc oì Eerly Oróvicien eqe (Buncize-i, 1983, and Chapien and orhers, 1971).

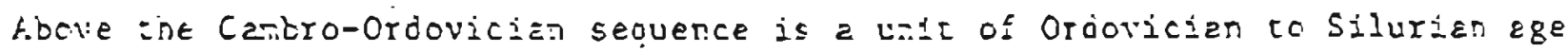
cosposed of variegazed cher and shaie, grey chert, dolouitic limestone end Einor feisic tuf̌ znd greenstone. This unit, the Chert tertent of Robinson ano

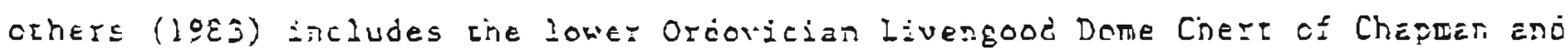


others (1980) and is equivalent to the Road River Formetion in the Yukon Territory (Chepwan and others, 1980, Robinson and others, 1983, and Iempelman Kluit, 1984).

Next, a rock sequence dominated by interlayered clastic sediments and gray chert of Paleozoic age that may be equivilent to rocks of the Earn Group in the Yukon (Robinson and others, 1983, Tempelman - Kluit, 1984), is apperenty transitional between rok of the Chert terrade and an overlying sequence of clastic turbidites of Middle and Dpper Devonian age.

Associated with the Devonian sequence near livengood is a dismembered and cectonically mixed mefic-cleramafic complex that includes gabbro, diorice, and serpentinite.

North of Livengood the Rampert Group of Yississippien to Triassic age is present and consists of a heterogenous mixture of gabbro, pillor basalt, diorire, chert, conglomerare, sendsrone, end shale (Brosgè and others, 1969). The Rampart Group may be equivalent to the Circle Volcanics of eastern Alaska and is jwrtaposed against the olier rocks near livengood alorg what is probably 2 faulted unconformicy (Robinson and ochers, 1983).

South of. Livengood a thick sequence of thin bedded, interlayered sandstone, shale and conglomerare of Jurassic ro Cretaceous age, (Mesozoic flysch untt of Robinson and others, 1983) unconformably or structurally overlies rocks of the Devonian clastic unit and rocks of the Carbrc-ordovicien unit.

Fetsic to interoediate plutors of Terticry or Late Crecrceous age intruode the Devorian clastic unit near Livengooo and the Yesozoic fiysch south of Iivengood.

Although tectonically eismembered, deteizec meppirg end sitatigraphic reconstructions in the region (Eigure 2) suggest that the stratigraphic succession from the Cambrian through the Devonian is continuous and probably represents the western continuarion of the Selhyn Easin in hlaske (Robinson and 
otbers, 1983, and Tempelman - Kluic, 1984, Kobinson, 1983, Smith, 1983, Bundzzen, 1983, and Albanese, 1983b), thus the metallogeny of the Iivengood area mej also be similiar to that of the Selugn Besin.

Gold placer deposits in the Livengood area have produced over 375,000 ounces of gold sibce their discovery in 1914. The most productive creeks in the area are centered in the Money Ka-b and Any Dome areas, east. Of Livengood and on" Livengood Creek, north and west of the Livengood towsite. Gold lode deposits in the Livengood area consist of small golo-antimony-quertz veins and minerelized felsic dikes that incrude the Siesozoic flysch and Devonian clastic unit and contain gold concentrations that Iange from 1.0 to $5.0 \mathrm{pps}$ (Robinsor and orhers, 1983, Allegro, 1984, anó Albanese, 1983a).

Zones of pyritic massive sulfide are present in rocks of the Paleozoic clastic and chert unit. (Eam Group) north of Livengood. The zodes contain very low base metal values however, their presence suggests a permissive environment for syngeneric metal concentrations in these rocks.

Rocks of the Chert rerrane (Road River Forwation) northwest of Livengood, art the host to stratabound limonitic cherc breccia horizons that contain gold concentration on the order of 1.0 to 1.3 pa. The origin of these mineralized zones is unknown, at present; they may represent either epigenetic zineralization or sygenetic, exinalivive depcsits (Robinson anci others, 1983).

Near Mit. Schwatka, northeast of Livengoci, zocks of the Chert rerzane contain zones of wessive salthsonice $\left(2 \pi \mathrm{CO}_{3}\right)$, hostec in silicifieo carbonate. The zinc vinezalizecion wzy represent remobilizei fri二ery syngenetic zinc concentazions ir. locks eglivalent to the Roat River Toration in Selwyn Easin, anc therefore cEz:ies significant implications concerite tie regional werallogeny and mineral pCientiEl oi these rocks. 


\section{Reźerences Citeó}

Albenese, M.D., 1983a, Geochemicel Reconnaissance of the Livengood B-3, B-4, C-3, and C-4 Quadrangles, Alaska; Summary of Data on Stream Sediment, Pen-Concentrate and Rock Samples: Alaske Division of Geological and Geophysical Surveys Report of Investigations No. 83-1, 55 p., 4 plates," scale $1: 63,360$.

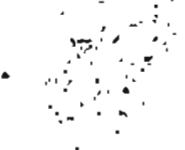

Albanese, M.D., 1983b, Bedrock Geologic Map of the Livengood B-4 Quadrangle, Alaska: Alaska Division of Geological and Geophysical Surveys Report oz Investigations No. 83-3, 1 plate, scale 1:40,000.

Allegro, G.A., 1984, Geology of the Old Smokg Prospect, Livengood C-4

Quadrangle, Alaska: Alaske Division of Geological and Geophysical Surveys Report of Investigations No. 84-1, 9 p., I plate, scale 1:120.

Bundtzen, T.R., 1983, Bedrock Geologic Outcrop Map of the Livengood B-3 Quadrangle, Alaske: Alaska Division of Geological and Geophysical Surveys Report of Investigations No. 83-6, l plate, scale 1:24,000.

Brosqe, H.P., Lanphere, M.A., Reiser, E.N., anci Chapmen, R.M., 1969, Probable Permian age of the Rampar Group, centrei f.Iaska: D.S. Geological Survey BLlletin 1294-B, P. B1-B18.

Chepsaz, R.M., heber, F.R., and Iabet, Bonc, 1971, Prelisinary Geologic Map of the Livengood Quadrengle, Alaske: U.S. Geological Surey Open-file Feport No. „, 2 plates, scale $1: 250,000$. 
Chapman, R.M., Weber, F.R., Churkia, Michael, Jr., anc Carter, Claire, 1980, The LIvengood Dome Chert, A Nev Oroovicien Fordation in Central Aleska, and its Relevance to Displacement on the Tintine Fault: U.S. Geological Survey Professional Paper $1126 \mathrm{~F}$.

Churkin, Michael, Jr., ind E-3bib, E.E., 1965, Occurence and Significance of Oldhamia, a Cambrien Trace Fossil, in East Central Alaska: U.S. Geological Survey Professional Paper 525D, p. D120-D124.

Gabrielse, B. _., Blusson, S.L., end Ruddick, J.A., 1973, Geology of the Elat River, Glacier Lake and higley Map areas, District of McRenzie and Yukon Ierzitory: Geological Survey of Canada, Menior No. 366,153 p.

' Robinson, M.S., 1983, Bedrock Geologic Map of the Livengood C-4 Quadrangle, Alaska: Alaska Division of Geological ana Geophysical Surveys Report of Investigations No. 83-4, 1 plate, scale 1:24,000.

Robinson, M.S., Smith, T.E., Bundtzen, T.R., and Albenese, M.D., 1983, Geology and Merallogeng of the Livengood Area, East-Central Alaske: Alaska Miners Conference, Anchorage, October 1983.

Srith, I.E., 1983, Bedrock Geologic Map of the Iivengood C-3 Quadrangle, Alaske: Heskia Division.of Geciogical and Gecphrsical Surveys Report of Investigations No. Ej-5, l plate, scele $1: 40,000$.

Iempelnan - Kluit, Dirk, 1984, Counierparts ć milaske's Tezranes in Yukon:

Corólileran Section of the Geological frsociarion of Canade, Vencouver, B.C., Cenade, Februery 1984, 4 y. 


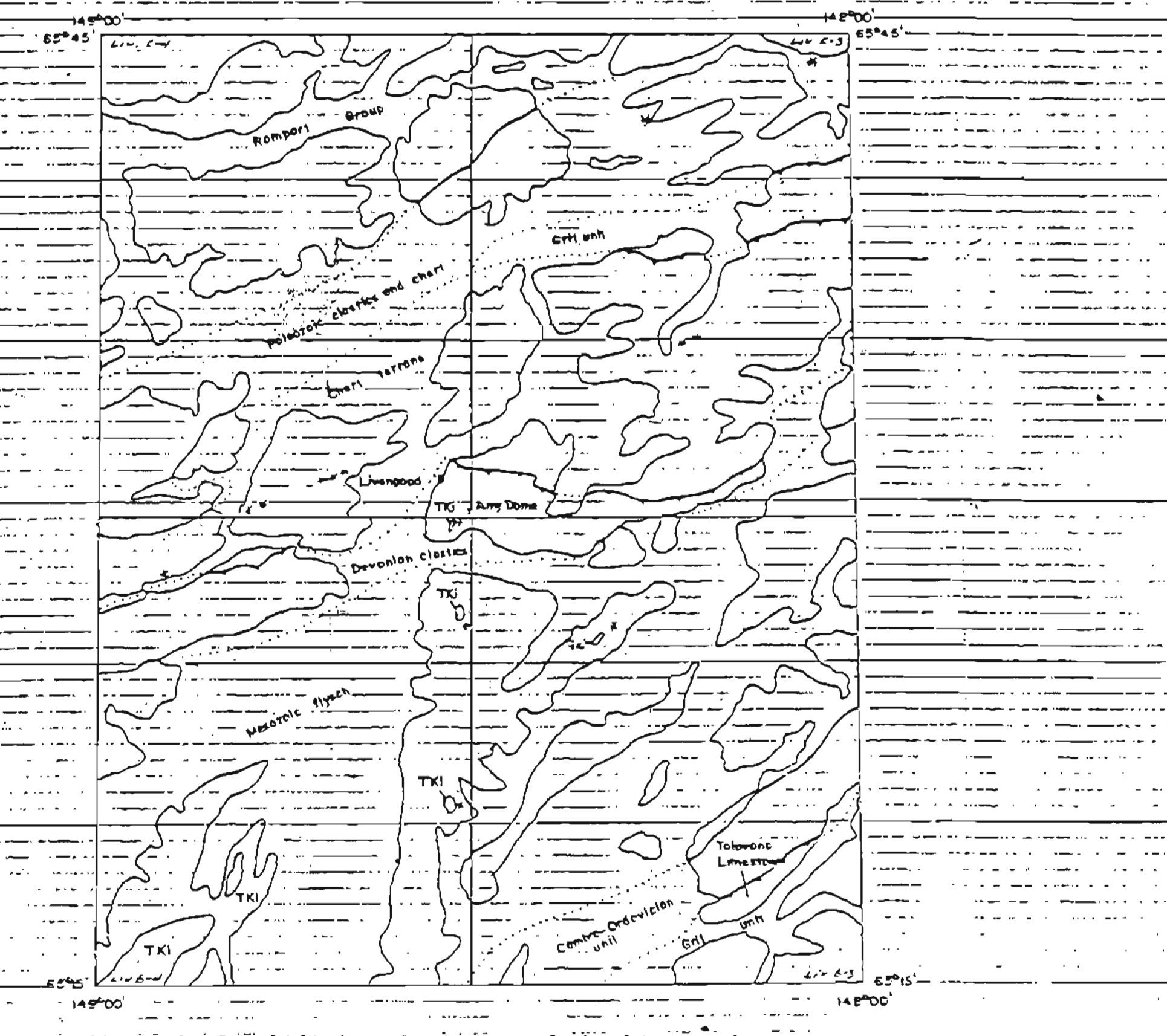

Figuré_l... Simplified geologic nap of the livergood ếé (frow Robinson, 1983; "Smith; rgs3; Bundtzen;'-I983;" -Albarese, - 1983; and Chapman and others, 1971)

* Indicares metal concencrations discussed in the rext 


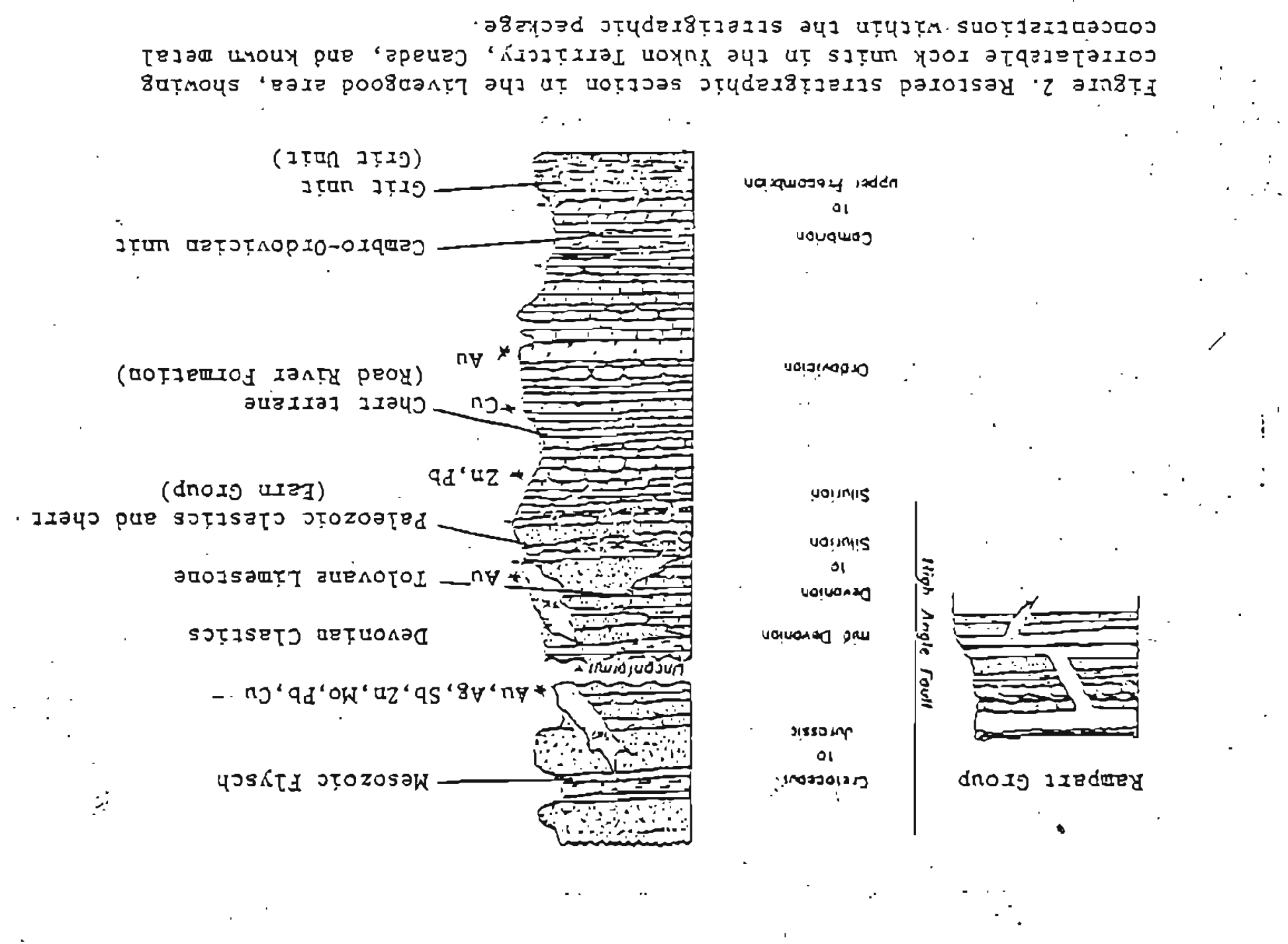

